\title{
Tama Samoa: Exploring Identities in Secondary School
}

\author{
Fuapepe Rimoni \\ School of Education, Victoria University of Wellington
}

This paper draws on a recent doctoral study which demonstrated ways that Tama Samoa (Samoan boys) enact their identities as Samoans authentically within the New Zealand secondary school context. Identity is complex and is not generally taken into consideration in the literature on education success and achievement of Pacific students in New Zealand. Recognising Pacific identities as being fluid, diverse and multi-dimensional, and engaging with the voices of tama Samoa enables a greater understanding and thus better support for tama Samoa and their educational success within the secondary school context.

Keywords: Pacific Islands, tama Samoa, adolescents, identities, identity formation, culture, diversity, talanoa.

\section{Introduction}

The Pacific male student in secondary school has been decidedly "silent" in the literature in comparison with other non-Pacific males and those of Pacific females. Both the male voices, and the reasons for their relative silence, are issues for further research, particularly given the data that suggest that Pacific males do not do as well overall in education as Pacific females (MOE, 2007). Therefore there are questions that need to be asked - What is known about tama Samoa? What is known about the complex, nuanced, and finely calibrated identities that sit beneath the bleak figures and graphs about educational underachievement? The experiences of tama Samoa are deeply embedded within wider social, economic, and political trends; their "voices" are shaped in part by these broader forces that construct and represent them as being historically "disadvantaged" and "underserved" socio-economically.

This article is derived from my PhD thesis (Dec, 2016): Tama Samoa Stories: Experiences and Perceptions of Identity, Belonging and Future Aspirations at Secondary School. I wanted to capture the voices of tama Samoa and how their experiences in secondary school influenced their identities. There were three themes that were highlighted in the thesis: identity, sense of belonging, and future aspirations. In this article, I will focus on one of the three themes. Within the theme of Identity I will briefly discuss some of the literature that discusses cultural identity from both Western and Pacific perspectives. An outline of the Pacific methodology used will be followed by a discussion on the complexities for tama Samoa and their identities and the implications of my study for educational policies that aim to ensure educational success for tama Samoa. The article will conclude with a reflection on tama Samoa voices. 


\section{Literature review}

\section{Cultural identity - A Western perspective}

Hall (1990) claims that a person's cultural identity is the foundation or groundwork on which every other aspect of their being is built. It is the cornerstone of what makes them who they are. Embracing one's culture often means practising a specific religion or wearing a certain type or style of clothing. Such practices create an outward, visible means of identifying a person as part of a particular culture or nationality. Hall summarises the relationship between identity and culture as:

Instead of thinking of identity as an already accomplished fact, which the new cultural practices then represent, we should think, instead, of identity as a 'production', which is never complete, always in process, and always constituted within, not outside, representation. (p. 222)

Hall considers that there are two aspects of cultural identity. One involves shared understandings of culture, a sort of collective one true self, hiding inside the many other, more superficial or artificially imposed selves, which people with a shared history and ancestry hold in common. The second recognises that, as well as the many points of similarity, there are also critical points of deep and significant difference which constitute "what we really are; or rather since history has intervened what we have become" (p. 223). That is, cultural identity is both an ongoing production of the group and of the individual where each site is capable of affecting the other.

In line with Hall, Clarke (2008) discusses cultural identity as being contributed to/located in a number of factors such as race, ethnicity, gender, and class. Clarke argues that:

Cultural identity brings quite a dark cloud over the question of identity in general. Defining your own self by another often leads to a strong sense of who we are not, or more likely who we don't want to be. (p. 527)

Clarke (2008), therefore, provides another angle to the understanding of cultural identity the negative connotation that the identity principle of individual cultures is in fact established through the principle of otherness. The reviewing of the Western literature of cultural identity, it appears as with any sort of individuality, cultural identity is a meeting point of several cross-cultural implications. Cultural identity, then, is of complex character, open to making its own changes to preserve its being in a new context of interests. In respect of this I continue in the following section to investigate Pacific perspectives on identity as this provides a cultural perspective through a Pacific lens.

\section{Cultural Identity - A Pacific perspective}

There is a growing number of Pacific and non-Pacific academics who are writing about Pacific perspectives on youth identities. These Pacific researchers, whose works have provided insights to the personal, social, and political issues that surround identity, provide valuable discussions in the area of identity. 
Mila-Schaaf (2010) identifies Pacific identities in terms of Pacific youth relationships with important others around them. For Mila-Schaaf, this includes not only the relationship Pacific youth hold with their cultural upbringing, but also with their mainstream Westernised upbringing. Mila-Schaaf's participants' narratives show that, for the second generation, acceptance within Pacific social spaces is not always easy to gain. They might identify as Pacific, but to be identified by others as Pacific was never assured.

Mila-Schaaf (2010) suggests that the challenges for second generation Pacific youth are quite severe in deciding how to go about strengthening their self-identity as Pacific individuals. Mila-Schaaf's study indicates the importance of maintaining Pacific cultural values and the passing of these traditional cultural values to second and third and future Pacific generations in order to maintain Pacific identity. In my study, the stories from tama Samoa of building identity within the secondary school setting provided an opportunity to build on Mila-Schaaf's understandings by examining what the tama Samoa perceived to be influences and experiences that support and develop their identity as tama Samoa.

According to Anae (1997), secure identities can be reached by Pacific youth going through a pathway, or as Anae suggests, a series of rites of passage. Through these rituals the Pacific individual is challenged to have the right to be a New Zealander or to be "a Samoan" (p. 128). Anae suggests that once a Pacific individual is successful in negotiating his or her identity, this will eventually lead to a secured identity; that for young Samoan individuals to go through this process they must thoroughly understand and be involved with Samoan customs and culture.

Anae's research $(1998,2001)$ into the identity journey of New Zealand-born Samoans highlights a series of stages that the New Zealand-born Samoans experience. She suggests that many may experience a period of "Identity Confusion" followed by a "Time Out" period where individuals act out their confusion, explore other lifestyles, leave their church, and in some cases adopt a more general Pacific identity. Anae (1998) also speaks of a "Secured Identity" which is marked by a persistent Samoan self-concept where one finds resolution between internal and external conflicts in what it means personally to be a New Zealand-born Samoan.

Tiatia (1998) examines the tensions in the relationship between Pacific youth and the church, and uses the voices of youthful participants themselves to describe these tensions. Tiatia's "Caught between two cultures" explores the dilemma of being Pacific people in a European society which does not understand their cultural uniqueness, and of being "the silenced Western educated voice" (p. 55), ignored within Pacific cultures due to being regarded as a threat to cultural traditions.

Tupuola (1998) points out that using theoretical development stages such as Maslow's (1954) "self-actualising person" can be problematic for the reason that "the notion of a personal identity is a social-cultural construct, not a development" (p. 150). She makes an argument for "the notion of identity achievement being limited and somewhat unrealistic because it makes the assumption that this stage, as defined by Western theorists, is attainable universally" (p. 58). Tupuola explicitly questions the idea of an "achieved identity" born of response to crisis. In her article "Pasifika Edgewalkers: complicating the achieved identity status in youth research" (2004) Tupuola explicitly questions the idea of an "achieved identity" born of response to crisis.

Building on her doctoral research, Tupuola's interest in diasporic and transnational youth identity privileged a model of continued negotiations, as opposed to Anae's quest for an arrival in the identity journey via the practice of fa'aSamoa (Samoan way). This idea, 
described as "edgewalking" (p. 14), privileges the idea of shifting and active negotiation between the borders of the worlds in which Pacific young people are connected, a conceptualisation that hooks into wider global discussions of postmodern and "borderland" identities. Tupuola also noted the importance of providing adolescents with a sense of space to develop their own sense of identity within various environments. This idea can be beneficial for tama Samoa as their identity may differ depending on the situation and environment, a possibility that applies to both cultural and social identity.

Increasingly used as a health model for Pacific people, Pulotu-Endemann's (2001) Fonofale model is represented metaphorically as a fale (traditional Samoan house). The structures that comprise the fale represent different factors that are important for the overall health of a Pacific individual. The foundation represents family, the foundation for all Pacific cultures. The roof represents beliefs and cultural values considered to be the shelter for life. Four posts between the foundation and roof represent the spiritual, physical, mental, and other aspects of life that form the connections between family and culture. PulotuEndemann's Fonofale model provides an example of what needs to be considered when trying to understand Pacific adolescents. The use of Pacific metaphor to explain or describe identity from a Pacific perspective highlights the Pacific element within research on Pacific people.

Anae (1998), Tiatia (1998), Tupuola (1993) and, more recently, Mila-Schaff (2010) each identify crucial elements important in the identity of Pacific youth including tama Samoa. What is clear from these studies of Anae, Tiatia, Tupuola, and Mila-Schaff is that to provide a clear description of identify formation for Pacific adolescents - including tama Samoa - a Pacific lens and theoretical framework must be considered, as Westernised ways of theorising may not be sufficient.

\section{Methodology - Pacific frameworks}

The use of the fa'afaletui framework is considered both a methodology and a method for collecting data. According to Tamasese Peteru, Waldergrave, and Bush (2005), the purpose of developing the fa'afaletui research methodology was to provide a rigorous research method that would be "relevant and acceptable in a Samoan cultural context". The fa'afaletui methodology "avoided the danger of Western interpretation and meaning construction and enabled an authentic Samoan-based approach" through an exploration of the experiences of Samoan people and "the meanings they construct around critical mental health issues and definitions" (p. 301).

Fa'afaletui is a technique or process well suited to conducting research in Samoan contexts (Tamasese et al., 2005). Tamasese et al. (2005) claim that the fa'afaletui framework facilitates the gathering and validation of important knowledge within the Samoan culture. Originally developed to enhance mental health service provision in emigrant Samoan communities in New Zealand, fa'afaletui is considered sensitive and responsive to Samoan cultural norms in that context, and to provide a sound basis for research into health needs and the development of health services consistent with Samoan lifeways (Tamasese, 2008; Tamasese et al., 2005).

To convey an understanding of the term fa'afaletui, it was important to provide a clear definition for the purposes of my study. Tuafuti (2011) defines the term from a linguistic perspective. Fa'a is the causative prefix used with a large number of bases and serving many 
separate functions, which cause someone or something to have or to do something. Fale means house. The word tui in this concept means to "thread through." Tuafuti's definition interlinks well with the literal translation of fa'afaletui as identified by Goldring (2006) in her Master's thesis: capacity building and knowledge sharing between people in communities of practice such as house building.

To ensure successful outcomes, cross-cultural projects should be undertaken by way of concepts indigenous to the culture in question. Fa'afaletui is a research framework that enables the collection, sharing, and validation of all the different levels of knowledge within the Samoan community, and the weaving of these knowledges into consensus about a given problem that reflects the Samoan worldview and is acceptable to those concerned (Tamasese, 2008).

Fa'afaletui is used both as a verb and as a noun. As a verb it refers to the methodology for collecting the data; in this case, the sharing of lived experiences and perceptions of the tama Samoa, and the perceptions of the nominated persons who were people nominated by tama Samoa as secondary participants I would interview, and they included family members, girlfriends and school friends, along with contributions from the literature.

Fa'afaletui aims at building close relationships between the researcher and participants through collaboration. In this study the building of positive relationships with tama Samoa was achieved through an informal gathering at the beginning to get to meet the tama Samoa and share a meal, to allow for this relationship to form. As a noun, fa'afaletui refers to the results of actual sharing, that is, what emerged from the various stages of analysis of the data. Fa'afaletui helped me to weave together the collective knowledge and perspectives of the tama Samoa and to reach a consensus about tama Samoa and their understandings of school life experiences. For all these reasons the fa' afaletui framework was deemed culturally and methodologically appropriate to capture the voices of tama Samoa.

The research method for data gathering in this research was talanoa through semistructured interviews and focus groups. Vaioleti (2006) describes the concept of talanoa as a conversation, a talk, an exchange of ideas or thinking, whether formal or informal. Using talanoa for engaging with tama Samoa built confidence amongst the group particularly using the focus group talanoa to build the relationship. The talanoa process is a good example of both a method and a methodology which uses formal or informal discussion in Pacific research. The Talanoa process is a data gathering interviewing method which can be used in one-on-one interviews or focus group discussions, and is also a useful method/methodology to use across disciplines.

\section{Participants}

The twelve tama Samoa were born and grew up in the Hutt Valley area of Lower Hutt, Wellington, some with both full Samoan heritage and others being a blend of ethnicities including Samoan heritage, and they ranged from 16-17 years of age. They were nominated by school principals from secondary schools across the Hutt Valley ranging between a boys' only secondary school, a co-education secondary school and a Catholic secondary school. It is also important to note that pseudonyms were used to safeguard their identities, and the names of the twelve disciples from the Bible were used. 


\section{Discussion - Complexities in tama Samoa identities}

In 2008, the New Zealand Ministry of Education funded a research project "Literature review on the experiences of Pasifika learners in the classroom" led by Dr Bruce Ferguson. This project identified the need to address the plural sense of the concept of "identities". The authors noted the importance of acknowledging the many identities taken on by Pacific students and pointed out the need to attend to "the multiple island nations subsumed within the term "Pasifika" (Ferguson, Gorinski, Wendt-Samu, \& Mara, 2008, p. 25). They also challenged readers to reflect more deeply on "the expectations placed on students whose parents are immigrants, or second or third generation New Zealanders" (Ferguson et al., 2008, p. 25).

Like other Pacific Islands students, tama Samoa in New Zealand occupy a number of different worlds (Hawk \& Hill, 1998). They experience connection with their family, their culture or cultures, possibly a connection with their church, the connection with their school, the connection with their peers, and a connection with the Westernised way of living of a wider society. All these connections are a reality for them, each connection being valuable and important. Hawk and Hill's findings resonate with the findings from my study, in that tama Samoa live with multiple identities, and walk within each identity as a part of their everyday lives. While tama Samoa enter into secondary school already dealing with multiple identities, during their secondary school years new identities are forming, and through this experience tama Samoa highlight the importance of both their experiences and those of people who influence their identity.

For tama Samoa in my research there was no hesitation about providing perceptions of themselves. However, they presented themselves in various differing manners, and the amount of detail they shared was also varied. It was, however, clear that their perceptions of themselves were connected to certain influences such as the home, and, especially, their relationships with their friends. It was also clear from the talanoa that the connection tama Samoa have with their peers is a strong influence on their development of who they are as individuals in the secondary school setting. In focus group talanoa, each tama Samoa spoke of the need to be an individual who valued friendships, being there for his mates, and being the type of individual who would show responsibility for the sake of his mates. Tama Samoa emphasised the importance of having quality relationships with others in order to maintain a positive experience during secondary school.

These findings resonate with Mila-Schaaf's (2010) interrogation of second generation Pacific people's conception of their own identity in terms of their relationship with important others. The ideas of Fine (2004) and Spano (2004) also relate to the ideas shared by tama Samoa, highlighting the importance and influence of others around them to play a key role in maintaining positive relationships within a school environment.

I have always been a good student, but I also enjoy my friends. I may not be doing my best at school so I would consider myself a steady achiever at school. I am not a lazy student but I don't want to be a top student because my friends will give me grief about it. (Patolomaio: SS)

Jackson and Dempster (2009) explain how boys in general construct themselves as having a natural ability that allows them to perform well with little effort in order to be both successful and acceptable in the eyes of their peers. However, the Samoan secondary student has the added dimension of cultural conflict to deal with; in particular they may challenge their 
traditional role in, and the expectations of, their family in the light of what they see as the new societal norms. Silipa (2008) describes the conflicts and stresses a Samoan student faces as "wavering" as they move from one situation to another. The tensions of conflict and stresses were identified by most tama Samoa in my study: they indicated that when they attend class it is important that they show they are trying to perform their best in front of their classmates so that they do not seem to be lacking in academic ability. Timoteo confirms this by stating his own experience of being in class where he is the only tama Samoan:

You're thinking "Oh I'm the only Islander there". I've got to like get it, because, you know, the Asians and Indians they're always smart and stuff, pressure like just to keep up with them and perform at their level, but they look at and you feel like they are thinking "Should you really be here?" (Timoteo: F)

However, this is not necessarily the case when they are amongst their own Samoan friends. Here they feel a responsibility to appear "naturally" bright and confident so that they are seen as somebody that others can approach if they need support or a friend. Some tama Samoa expressed the pressure of trying to keep up this performance in order to not let down their friends; however, the dual ways in which they present themselves also means that family members and school teachers have high expectations.

Linked to this is the need to avoid sharing too much of who you are to your friends. According to Abraham (2008), one way that boys may continue the uncomplicated achievement of communication while still maintaining their relaxed attitude in school is to embrace a counter-school culture in public, but to value learning and academic achievement in private.

To conclude this paper, I will now review key learnings from the study, which aimed at enabling the Samoans to describe their experiences of developing their identities within secondary school. Through the talanoa process with tama Samoa, it became clear that most of the tama Samoan identity developments were influenced by their secondary school experience. Tama Samoa noted the need to have multiple identities for different purposes. These included: awareness of others' perceptions of them; accessing teacher attention; as a survival strategy to be applied in different learning environments; and for the purposes of being amongst and relating to mates and peers. The tama Samoa described and explained why it was important and necessary to formulate multiple identities during their time at secondary school.

The tama Samoa also discussed the importance of being confident in knowing who they were, so that peers, teachers, and close friends were able to identify who a tama Samoa was in relation to the circle of friends and others that tama Samoa connected and communicated with during secondary school. As described by Nahkid (2003):

In constructing our identity, we build (with what we know of our past and our historical experiences), using the present to shape how we see who we are. That is not all that forms our identity. It is hollow unless we fill within it visions of what we hold for ourselves in the future, and how we see ourselves being. It is not only the state of being who we are, but who we are to become. (p. 303)

Whilst there has been limited research that focuses primarily on understanding the experiences of tama Samoa in New Zealand secondary schools from the perspective of the 
boys themselves, it is important for policy makers to pay particular attention to Pacific students including tama Samoa. Policy makers can be more responsive to the unique experiences of tama Samoa and other Pacific Islands students, not only academically, but also in terms of their social experiences in secondary school. The findings from my study can be used to inform policy makers about how to support tama Samoa in secondary school environments and to support and develop initial teacher education programmes. Based on the findings of the study it is recommended that:

- $\quad$ Existing policies and guidelines review how to highlight successful strategies to support tama Samoa in secondary schools such as the opportunities to demonstrate leadership qualities and responsibilities.

- Policy documents be updated on a regular basis so that they continue to address the needs of tama Samoa and tama Pacific within secondary school settings.

- $\quad$ Updated documents such as curriculum, Education reports and Pacific Education Plans should continue to be shared with the community and school management through talanoa.

- $\quad$ Appropriate and sufficient support - such as funding and teacher support - be provided to secondary school environments in order that they can action policies that will support tama Samoa and other Pacific Islands students.

Overall, tama Samoa identities are influenced by many of their secondary school experiences. The development of their self-identity is through the connections they have with others such as peers, and close friends. Their multiple identities are used as a tool to adapt in different contexts and most importantly their cultural identity, again, is based on the group they choose to surround them as well as the knowledge that tama Samoa have from their family backgrounds. These many identities all connect to what makes a tama Samoa, and learning to build these many different identities is a major part of their secondary school experience.

\section{References}

Abraham, J. (2008, January). Back to the future on gender and anti-school boys: A response to Jeffrey Smith. Gender and Education, 20(1), 89-94.

Anae, M. (1997). Towards a NZ-born Samoan identity: Some reflections on "labels". Pacific Health Dialog, 4(2), 128-137.

Anae, M. (1998). Fofoa-i-vao-'ese: The identity journeys of NZ-born Samoans (Doctoral thesis). University of Auckland, New Zealand. Retrieved from https://researchspace.auckland.ac.nz/docs/uoa-docs/rights.htm

Anae, M. (2001). The new Vikings of the sunrise: New Zealand-borns in the information age. In C. Macpherson, P. Spoonley, \& M. Anae (Eds.), Tangata o Te Moana Nui: The evolving identities of Pacific peoples in Aotearoa/ New Zealand (pp. 101-121). Palmerston North, New Zealand: Dunmore Press.

Clarke, S. (2008). Culture and identity. In T. Bennett \& J. Frow (Eds.), The SAGE handbook of cultural analysis (pp. 510-530). London: Sage.

http://dx.doi.org/10.4135/9781848608443.n25 
Ferguson, P., Gorinski, R., Wendt Samu, T., \& Mara, D. (2008). Literature review on the experiences of Pasifika learners in the classroom. Wellington, NZ: Ministry of Education.

Fine, G. A. (2004). Adolescence as cultural toolkit: High school debate and the repertoires of childhood and adulthood. The Sociological Quarterly, 45(1), 1-20.

Goldring, M. (2006). Weaving language with identity; The story of Samoan secondary students: Letoga: A precious thing (Master's thesis). Christchurch College of Education, New Zealand. Retrieved from http://ir.canterbury.ac.nz/bitstream/10092/1053/1/ thesis_fulltext.pdf

Hall, S. (1990). Cultural identity and diaspora. In J. Rutherford (Ed.), Identity, community culture (pp. 222-237). London: Lawrence \& Wishart.

Hawk, K., \& Hill, J. (1998, December). Teaching students under stress: Implications for schools and teachers in multi-cultural schools. A paper presented to NZARE Conference, Dunedin, New Zealand.

Jackson, C., \& Dempster, S. (2009). 'I sat back on my computer... with a bottle of whisky next to me': Constructing 'cool' masculinity through 'effortless' achievement in secondary and higher education. Journal of Gender Studies, 18(4), 341-356.

Maslow, A. (1954). Motivation and personality. New York, NY: Harper \& Row.

Mila-Schaaf, K. (2010). Polycultural capital and the Pasifika second generation: Negotiating identities in diasporic spaces (Doctoral thesis). Massey University, Albany, New Zealand. Retrieved from http://mro.massey.ac.nz/bitstream/handle/10179/1713/02_ whole.pdf?sequence=1\&isAllowed=y

Ministry of Education. (2007). Pasifika education plan monitoring report. Wellington, NZ: Author.

Nakhid, C. (2003). "Intercultural" perceptions, academic achievement, and the identifying process of Pacific Islands students in New Zealand schools. The Journal of Negro Education, 72(3), 297-318.

Pulotu-Endemann, F. K. (2001). Fonofale: Model of health. Retrieved from http://www.hauora.co.nz/resources/Fonofalemodelexplanation.pdf

Rimoni, F. (2016). Tama Samoa Stories: Experiences and Perceptions of Identity, Belonging and Future Aspirations at Secondary School (PhD thesis). Victoria University of Wellington, New Zealand.

Sheets, R. (2005). Ethnic identity and its relationship with school achievement. Multicultural Education, 13(4), 58-60.

Silipa, S. (2008). Fanaafi ofa'amalama: A light within the light: Nurturing coolness and dignity in Samoan students' secondary school learning in Aotearoa/New Zealand (Doctoral thesis). College of Education, University of Canterbury, Christchurch, New Zealand. Retrieved from http://hdl.handle.net/10092/2886

Spano, S. (2004). Research facts and findings. Retrieved from http://libvolume4.xyz/ homescience/bsc/semester5/humandevelopment2hdfs4/adolescence/adolescencetu torial1.pdf.

Tamasese, T. K. (2008, September). Achieving wellbeing with Pacific peoples, families and communities: Considerations of gender, culture and socio-economic contexts. Paper presented at Creating Futures Conference, Cairns, QLD, Australia.

Tamasese, K., Peteru, C., Waldegrave, C., \& Bush, A. (2005). Ole Taeao Afua, the new morning: A qualitative investigation into Samoan perspectives on mental health and 
culturally appropriate services. Australian and New Zealand Journal of Psychiatry, 39(4), 300-309.

Tiatia, J. (1998). Caught between cultures: A New Zealand-born Pacific Island perspective. Auckland, NZ: Christian Research Association.

Tuafuti, P. (2011). Multiple challenges in research within the fa'asamoa context. Pacific-Asian Education, 23(2), 33-42.

Tupuola, A. M. (1993). Raising research consciousness, the Fa'a Samoa way. New Zealand Annual Review of Education, 3, 169-190.

Tupuola, A. M. (1998). 'Adolescence': Myth or reality for Samoan women? Beyond the stagelike toward shifting boundaries and identities (Unpublished doctoral thesis). Victoria University of Wellington, New Zealand.

Tupuola, A. M. (2004). Pasifika edgewalkers: Complicating the achieved identity status in youth research. Journal of Intercultural Studies, 25(1), 87-100.

Vaioleti, T. M. (2006). Talanoa research methodology: A developing position on Pacific research. Waikato Journal of Education, 12, 21-34.

Fuapepe Rimoni is a lecturer in Pacific and Multi-ethnic Education at the Faculty of Education at Victoria University of Wellington. She has recently completed her PhD titled, Tama Samoa Stories: Experiences and Perceptions of Identity, Belonging and Future Aspirations at Secondary School. Fuapepe is of Samoan descent, daughter of the late Lake and Tuipala Rimoni. Over the years she has been a classroom teacher, advisor and lecturer. Her research interests are in Pacific education, Pacific boys' education, identity formation, and belonging in the secondary school context.

Email: fuapepe.rimoni@vuw.ac.nz 